ANDRZEJ STROYNOWSKI

Uniwersytet im. Jana Długosza w Częstochowie

(iD) ORCID ID: 0000-0002-4747-3636
WŁADZA I POLITYKA

W CZASACH NOWOŻYTNYCH

DYPLOMACJA I SPRAWY WEWNĘTRZNE

\title{
Opinie księdza Jędrzeja Kitowicza o dyplomacji i dyplomatach
}

\author{
Opinions of priest Jędrzej Kitowicz \\ about diplomacy and diplomats
}

\section{Wstęp}

$\square$

reguły nasza wiedza o poglądach i opiniach w dawnych wiekach opiera się na przekazach pozostawianych przez rządzących lub elitę polityczną. Mniej natomiast wiadomo o poglądach i opiniach wyrażanych przez przedstawicieli niższych warstw społecznych. Stąd tak wielkie znaczenie mają prace i zapiski księdza Jędrzeja Kitowicza, z których formę najbardziej skończoną pod względem kompozycyjnym i literackim ma Opis obyczajów za panowania Augusta $I I I^{1}$, cieszący się też największą popularnością i mający wpływ na kierunek poszukiwań historyków². Kolejną niedokończoną przez Kitowicza pracą są jego Pamiętniki czyli historia polska, które nie zyskały już tak jednoznacznej oceny pod względem wartości historycznej³ ${ }^{3}$ Ostatnio zaś ukazała się jego Korespondencja i gazetki rękopiśmienne ${ }^{4}$. Ten materiał powinien

${ }^{1}$ J. Kitowicz, Opis obyczajów za panowania Augusta III, oprac. R. Pollak, Wrocław-Warszawa-Kraków 1970.

2 J.S. Bystroń, Dzieje obyczajów w dawnej Polsce. Wiek XVI-XVIII, t. I-II, Warszawa 1976; Z. Kuchowicz, Obyczaje staropolskie XVII-XVIII w., Łódź 1977; idem, Cztowiek polskiego baroku, Łódź 1992.

3 J. Kitowicz, Pamiętniki czyli Historia polska, oprac. i wstęp P. Matuszewska, komentarz Z. Lewinówna, Warszawa 1971. Dawniej oceny były skrajnie różne: od pełnego uznania Karola Sienkiewicza do negacji Władysława Konopczyńskiego, ale też bez nich nie można wyobrazić sobie książki Wacława Szczygielskiego. Por. K. Sienkiewicz, Skarbiec historii polskiej, t. I, Paryż 1839, s. 16; W. Konopczyński, Szkoda, że to nie powieść, „Tygodnik Powszechny” 1951, nr 51-53, s. 6; W. Szczygielski, Konfederacja barska w Wielkopolsce 1768-1770, Warszawa 1970.

${ }_{4}^{4}$ J. Kitowicz, Korespondencja i gazetki pisane Jędrzeja Kitowicza z lat 1771-1776, oprac. T. Ciesielski, S. Górzyński, F. Wolański, Warszawa-Bellerive-sur-Allier 2017. 
pozwolić na odtworzenie poglądów nie tylko ciekawej i niejednoznacznej postaci Kitowicza $^{5}$, ale również średniej szlachty, z którą wiązał się doświadczeniami oraz wyznawanym systemem wartości, różniąc się jednak od ogółu talentem pisarskim i zmysłem obserwacji. Jego spuścizna może też obrazować stan umysłowości i poglądów niższego duchowieństwa ${ }^{6}$. Pamiętać tylko trzeba, że Kitowicz - pomimo swojego doświadczenia i rozległych kontaktów - nigdy nie był czynnym politykiem i podobnie do większości społeczeństwa miał być człowiekiem „pozbawionym zmysłu politycznego, rezonującym dość prymitywnie”, jak pisał Roman Pollak ${ }^{7}$.

\section{Łatwowierność Kitowicza}

Rzecz jasna jego prace nie dają podstawy do poznania tajników polityki i dyplomacji, gdyż tylko z oddali analizował przychodzące wiadomości, często wykazując łatwowierność czy naiwność. Nawet gdy poznał doniesienia Jakuba Psarskiego z Petersburga o traktacie rozbiorowym, to nadal łudził się relacjami ze Śląska donoszącymi

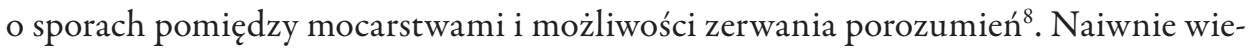
rzył też w możliwość uzyskania pomocy ze strony Francji, Hiszpanii, Anglii i Szwecji oraz w rozpoczęcie przez papieża Klemensa XIV zaciągu 20 tys. Szwajcarów do walki z Prusami, które już zaczęły zajmować Pomorze i Warmię? J Jednak wkrótce (21 III 1773) musiał stwierdzić, że pisma te „żadnego nie otrzymały responsu, czy przez nienawiść do osoby, czy przez niedbałość o polskie interesa"10. W tym czasie wierzył jeszcze (18 IV 1773) w doniesienia o trosce sułtana o sprawy polskie, wyrażające

5 Trudno bowiem zgodzić się z ograniczaniem jego dokonań do pisarstwa i posługi kapłańskiej, skoro wcześniej przez lata podejmował się najróżniejszych zadań i funkcji, szczególnie zaznaczając się w czasie konfederacji barskiej (do której przystąpił, mając już 40 lat) i dopiero po jej upadku, być może dopiero osiągnąwszy lat 50 wstąpił do stanu duchownego (stało się to między 1772 a 1778 r.), zyskując stabilizację życiową i finansową, co pozwoliło mu skupić się na pisaniu swoich prac. Por. J. Kitowicz, Korespondencja, s. 34-38, 61-75; Z. Lewinówna, Wstęp, [do:] J. Kitowicz, Pamiętniki, s. 27-28.

${ }^{6}$ S. Witecki, Przekaz kulturowy w parafiach katolickich na obszarze Rzeczypospolitej Obojga Narodów czasów stanistawowskich, Kraków 2019.

7 R. Pollak, Wstęp, [do:] J. Kitowicz, Opis obyczajów, s. XX.

${ }^{8}$ J. Kitowicz, Korespondencja, s. 105. Warto jednak zauważyć, że nawet bez porównania bardziej obyci z polityką Czartoryscy okazywali podobną łatwowierność i przesadny optymizm w ocenie międzynarodowego położenia Rzeczypospolitej. Por. J. Michalski, Dyplomacja polska w latach 1764-1795, [w:] Historia dyplomacji polskiej, t. II (1572-1795), red. Z. Wójcik, Warszawa 1982, s. 694.

9 Tak pisał 15 X 1772 r. (J. Kitowicz, Korespondencja, s. 109-110). Były to tylko jego marzenia, ponieważ papiestwo w tym czasie miało znacznie poważniejsze problemy w stosunkach z państwami burbońskimi, zakończone likwidacją zakonu jezuitów. Por. J. Michalski, Dyplomacja polska, s. 537.

${ }^{10}$ J. Kitowicz, Korespondencja, s. 128. Nie przeszkodziło mu to jednak jeszcze 8 V 1773 r. liczyć się z zawarciem sojuszu Francji, Anglii i Hiszpanii w obronie Polski. 
się w odrzuceniu propozycji traktatu w Rosją, jak też w zachęcaniu Szwecji do podjęcia działań zbrojnych przeciw Rosji ${ }^{11}$.

Z czasem sam przyznał się do nadmiernego optymizmu, pisząc:

Jużeśmy sobie pięknie poukładali obroty cudzoziemskich dworów: Hiszpanię, Francję, Anglię, Holandię, Sardynię złączyliśmy w jeden alians offensive et defensive gwoli utrzymania Polski od rozerwania. Turka z Moskwą pogodziwszy, obróciliśmy na cesarza, a Moskwę z dopiero wspomnianymi aliantami na Prusaka. Danię i Szwecję chcieliśmy mieć neutralną, aż gdy teraz daje się nam słyszeć, że te dwie potencje zawarły ścisły alians z Moskwą ${ }^{12}$.

Mimo to nadal bezkrytycznie powtarzał wiadomości o zwycięstwach tureckich w wojnie z Rosją (jeszcze w lutym 1774 r.) ${ }^{13}$, chociaż dostrzegł już (we wrześniu 1773 r.) znamiona późniejszych zmian w układzie europejskich sojuszy. Z jednej strony miał to być sojusz francusko-prusko-turecki, a z drugiej rosyjsko-austriacki ${ }^{14}$, chociaż nastąpić to miało dopiero w trakcie prób realizacji przez Katarzynę II „planu greckiego”.15.

\section{Ocena wladców}

Od tak szczątkowej i często bałamutnej wiedzy o wielkiej polityce ważniejsze są jego ogólne opinie. Był republikaninem w sarmackim wydaniu i dlatego nie dostrzegał związku pomiędzy silną władzą państwa a szczęściem ludności. Z tego powodu chwalił panowanie Augusta III jako „słodkie”16. Uważał też istnienie dynastii saskiej za dużą wartość, szczególnie pomocną w polityce międzynarodowej. Stąd wierzył, że Katarzyna II, wbrew wcześniejszej obietnicy wspierania kandydatury Stanisława Poniatowskiego do tronu, gotowa była zmienić zdanie i ostatecznie poprzeć nowego elektora saskiego jako posiadającego poparcie dworów europejskich. Taką możliwość przekreślić miała tylko nagła śmierć elektora ${ }^{17}$.

11 Ibidem, s. 132.

12 Tak pisał 16 I 1774 r. (ibidem, s. 191). Wkrótce (22 I 1774) doszedł do jeszcze bardziej pesymistycznej oceny sytuacji, uznając brak możliwości określenia najkorzystniejszego układu sił w Europie i dostrzegania w każdym konflikcie nowego zagrożenia (ibidem, s. 195).

13 Ibidem, s. 201.

14 Ibidem, s. 158. Jednak już 29 XIII 1773 r. pisał o sojuszu francusko-hiszpańsko-angielskim, którego celem miała być nie tylko obrona Polski, lecz także utrzymanie równowagi europejskiej. Już w styczniu uzupełnił ten sojusz o Sardynię, Portugalię i liczył na przystąpienie do niego Szwecji oraz Holandii. Por. ibidem, s. 184-186.

15 L. Bazylow, Historia Rosji, Warszawa 1983, s. 352-353; W.A. Serczyk, Katarzyna II carowa Rosji, Wrocław 1983, s. 256, 265; R.H. Lord, Drugi rozbiór Polski, wyd. 2, Warszawa 1984, s. 37, 40, 47.

16 J. Kitowicz, Pamiętniki, s. 40, 119.

17 Podaje przy tym błędną datę 15 XII 1763 r., gdy faktycznie Fryderyk Chrystian elektor zmarł 17 XII 1763 r. Por. ibidem, s. 121; J. Michalski, Dyplomacja polska, s. 492. 
Ta ocena postawy Katarzyny II wiązała się z jego skłonnością do dostrzegania i wręcz pochwały obłudy w działaniach politycznych. Dlatego chociażby podkreślał zręczność Pugaczowa, który formalnie nie chciał władzy dla siebie tylko dla Pawła I, równocześnie wskazując na nieprawne podstawy władzy Katarzyny II ${ }^{18}$.

Z pewnym uznaniem pisał też o obłudnej postawie Fryderyka II, który w czasie bezkrólewia w odpowiedzi na interwencje prymasa Władysława Łubieńskiego w sprawie gwałtów czynionych w Wielkopolsce ${ }^{19}$ zasłonił się niewiedzą o takim postępowaniu oddziału Paszkowskiego i zapowiedział jego odwołanie. Jednocześnie wskazał na nieporównanie większe straty pruskie w czasie wojny, osłabiając tym rangę polskich zarzutów. W rzeczywistości zaś wkrótce wynagrodził Paszkowskiego, awansując go na pułkownika, a jego siostrę czyniąc przełożoną klasztoru trzebnickiego pod Wrocławiem ${ }^{20}$.

Bez sympatii, ale z uznaniem pisał ponadto o polityce Józefa II, który popchnął opozycję do zawiązania konfederacji barskiej.

Nieszczęśliwi i łatwowierni Polacy szukali protekcji naprzeciw jednemu zdrajcy u drugiego zdrajcy. Józef albowiem cesarz przez trzecie osoby (nigdy sam przez się) zwodził Polaków, iż byle się cały naród porwał do broni, namówi matkę, cesarzową Marię Teresę, że mu da pomoc; co było czystym oszukaństwem ${ }^{21}$.

To właśnie zręczna dyplomacja mocarstw miała prowadzić Rzeczpospolitą do zguby w czasie Sejmu Wielkiego, gdy

sejm warszawski napisał konstytucję 3 maja złudzony przyjaźnią króla pruskiego [...] Konfederacja targowicka widzi się być uplątaną w podobną obłudę dworu rosyjskiego, kiedy najgłówniejszego zamiaru swego, zepchnięcia z tronu króla, jest pozbawiana przez wyraźną zapowiedź, iż król królem zostać musi ${ }^{22}$.

Za szczególnie obłudne uznawał Prusy, które najpierw „podburzały” do zrzucenia rosyjskiej protekcji i nawet zawarły sojusz, a wkrótce uznały, że

18 „Wielka polityka w tej mierze utajona, nie mniej dla pospólstwa powabna, jako też dla panującej i wołanego na tron jej syna straszna”. Por. J. Kitowicz, Korespondencja, s. 217.

19 Rotmistrz Paszkowski, stacjonując z 60 huzarami w Poznaniu, ścigał jakoby zbiegłych z Prus poddanych i nakładał kontrybucje na polską szlachtę, gdy nie chciała ich wydać.

${ }^{20}$ J. Kitowicz, Pamiętniki, s. 126.

${ }^{21}$ Ibidem, s. 169. Podobnie opisał bytność Józefa II w Preszowie, gdzie zdołał uniknąć jakichkolwiek deklaracji, budując jednak nadzieje Generalności na uzyskanie pomocy austriackiej (ibidem, s. 175). Faktycznie w tym czasie cesarz już poszukiwał porozumienia z Prusami w sprawie przyszłego rozbioru. Por. J. Michalski, Dyplomacja polska, s. 514-515.

22 Podobnie postępować miały i inne dwory europejskie „z konstytucją 3 maja: milczały o niej rok cały, aż gdy pierwsza Moskwa oświadczyła przeciw niej swoją opozycją, dopiero też inne dwory naganiać ją poczęły". Por. J. Kitowicz, Pamiętniki, s. 549-550. 
konstytucja 3 maja wcale jest przeciwna dobrej przyjaźni sąsiedzkich dworów, że [...] mając wojnę z Francją, nie może kraju swego zostawić w tyle bez należytego obwarowania od jakowych szkodliwych buntów polskich i rozruchów, obwarować go zaś lepiej nie może jak przez rozłożenie wojska swego w krajach polskich.... ${ }^{23}$.

\section{Uznanie dla zręczności politycznej}

Cenił też zręczność polityczną, dostrzegając ją w wykorzystaniu doniesień dyplomatycznych informujących o przygotowaniach do nowego rozbioru dla przeprowadzenia Konstytucji 3 maja.

Na dowód tej prawdy [król] kazał czytać listy od ministrów polskich przy różnych dworach za granicą będących. Czytano tedy owe listy z Wiednia, z Berlina, z Francji, z Holandii, z Anglii, Szwecji i z Moskwy. Zewsząd jednostajnie donoszono, iż owy podział Polski już jest w gabinetach ułożony. Między donoszącymi najobszerniej rozwodził się z swoim doniesieniem Deboli, rezydent polski u dworu petersburskiego, opisując cały rozmiar i wszystkie ułożenia pomienionego podziału, iż jeżeli Stany polskie co prędzej temu nieszczęściu nie zabiegną, kraj polski we dwie najdalej niedziel będzie rozerwany (co by się tak prędko stać nie mogło, chyba cudem). Po przeczytaniu listów posłowie w sekretnej zmowie z królem będący pokazali po sobie wielkie zatrwożenie, spomiędzy których Linowski [...] obrócił mowę do króla, iż w okolicznościach tak niebezpiecznych nie widzi żadnego ratunku, tylko w jednym królu, którego mądrość jedyna może wyrwać ojczyznę z tej ostatniej toni ${ }^{24}$.

Cenił też spryt w działaniach politycznych, czego przykładem może być rozwiązanie przez Szczęsnego Potockiego sprawy szpiega tureckiego, który zagrożony ujęciem w obozie rosyjskim schronił się u Polaków. Na rosyjskie żądanie wydania go

Potocki odpowiedział Moskalom: Kiedy go w swoim obozie nie schwycili, nie mogą go mieć za szpiega ani on nie może go powierzyć ich indagacji bez narażenia przyjaźni tureckiej, pod słusznym konwojem odesłał go do obozu tureckiego. Taką roztropną grzecznością zjednał sobie u Turków wielki szacunek, ile że u tego narodu imię Potockich z dawna w wysokim zostaje poważaniu. Basza chocimski pisał do niego list pełen grzeczności i przyjaźni, tak ku Potockiemu, jako też ku całej Rzeczypospolitej Polskiej, której Porta Otomańska wiernie Polakom dochować pragnie ${ }^{25}$.

${ }^{23}$ Ibidem, s. 550.

${ }^{24} \mathrm{Ibidem}$, s. 481. Opis ten trafnie oddaje atmosferę sesji, lecz nie jej szczegóły, chociażby mylnie wskazując Aleksandra Linowskiego, gdy w rzeczywistości takie wyzwanie pod adresem króla sformułował Ignacy Potocki. Por. [A. Siarczyński], Dzień Trzeci maja roku 1791 w Warszawie, Kraków 1891, s. 33-34; J. Dihm, Trzeci maja, Kraków 1932, s. 16-20; E. Rostworowski, Ostatni król. Geneza i upadek Konstytucji 3 maja, Warszawa 1966, s. 232; K. Zienkowska, Spisek 3 Maja, Warszawa 1991, s. 95; B. Szyndler, Czy Sejm Czteroletni uchwalit Konstytucje 3 maja? (Na tropach mitów narodowych), Warszawa 2010, s. 17-21.

25 J. Kitowicz, Pamiętniki, s. 404. 
Jednocześnie przeceniał rolę jednostki w wielkiej polityce, co wyrażało się w bezkrytycznej wierze w to, że do wojny Rosji z Polską doprowadził Szczęsny Potocki, najpierw przegrywając w karty z Aleksandrem Bezborodką znaczne sumy, a później wydając na przekupienie rosyjskich ministrów dwa miliony złotych, by ostatecznie pozyskać zgodę samej Katarzyny II, która „gorzałką gdańską, trunkiem swoim najmilszym upojona, dała się nakłonić..." ${ }^{26}$. Natomiast polską odpowiedź na notę Jakowa Bułhakowa o wkroczeniu wojsk rosyjskich uznał za nazbyt pokorną, zapowiadającą bojaźliwe prowadzenie wojny. Decydująca w tym miała być postawa króla, którego Kitowicz podejrzewał, że ze strachu, „nie śmie bardzo rozdrażnić monarchini rosyjskiej, swojej stworzycielki, że najpierwszym jego jest celem utrzymać się na tronie, a z resztą niech się, co chce, dzieje”27.

\section{Stosunek do dyplomatów}

$\mathrm{Z}$ reguły z niechęcią odnosił się do dyplomatów. Widać to już w szczególnie lekceważącym tonie opisu wjazdu poselstwa tureckiego do Warszawy w 1755 r., w jakim podkreślał kontrast pomiędzy dostojnym posłem a jego orszakiem, w którym „wlokła się reszta motłochu tureckiego, w krótkich siermiężkach, z piersiami rozmamłanymi, w szarawarach płóciennych, w zawojach brudnych" ${ }^{28}$. Poselstwo to zresztą miało tylko ceremonialny charakter.

Jeszcze mniejsze znaczenie przywiązywał do późniejszego poselstwa polskiego do Stambułu, gdzie szambelan Tomasz Aleksandrowicz długo nie był uznawany za posła i dopiero pod naciskiem rosyjskim został z lekceważeniem przyjęty na audiencji, na której wyrażono uznanie koronacji Stanisława Augusta ${ }^{29}$. Bardziej oburzył się na Gedeona Benoit, który odrzucał możliwość wysłania Franciszka Kwileckiego z poselstwem do Berlina, gdzie jako niedawny konfederat barski nie miał uzyskać uznania ${ }^{30}$. Widział jednak skuteczność działań pruskich na sejmie rozbiorowym, gdy trzech posłów z delegacji sejmowej odmówiło podpisania traktatów „co przypisują robocie berlińskiej, okazji do pokłócenia się z innemi dwiema szukającego" ${ }^{31}$.

26 Ibidem, s. 502. Oczywiście jedynym prawdziwym elementem tej opowieści mogła być tylko znacząca pozycja Bezborodki na dworze carskim. Por. J. Michalski, Dyplomacja polska, s. 627-628.

27 Ibidem, s. 506, 510.

28 Ibidem, s. 73.

29 Ibidem, s. 74; J. Michalski, Dyplomacja polska, s. 542-543.

30 J. Kitowicz, Korespondencja, s. 84. Rzeczywiście jego misja nie przyniosła żadnych rezultatów, chociaż po sześciotygodniowym oczekiwaniu zastał przyjęty - wbrew zdaniu Kitowicza z 8 VII 1772 r. - na audiencji przez Fryderyka II. Por. ibidem, s. 101; J. Michalski, Dyplomacja polska, s. 544.

31 J. Kitowicz, Korespondencja, s. 197. Podpisania ich odmówili posłowie: Antoni Biesiekierski, Franciszek Jerzmanowski, Franciszek Wilczewski. Por. D. Dukwicz, Rosja wobec sejmu rozbiorowego warszawskiego (1772-1775), Warszawa 2015, s. 224. 
Bardziej interesował się postawą dyplomatów rosyjskich, akcentując już celowy afront ks. Piotra Golicyna wobec odwołanego z Polski nuncjusza Angelo Duriniego, którego najpierw zatrzymał w Piotrkowie, by ostatecznie puścić bez spotkania z nim ${ }^{32}$. Szczególnie interesował się działaniami Otto Magnusa Stackelberga, który straszył możliwością rozszerzenia pruskich zdobyczy w przypadku dalszego oporu członków delegacji sejmowej33. Oburzał się na jego postępowanie,

bo poseł kiedy mówi od swego dworu, to nie żartuje, tylko to niedobrze, że ta deklaracja oświadczona jest publico przez gazetę prima aprilis, to się może nie sprawdzić, bo ten dzień jest zwodniczy. Luboć nas Polaków cudzoziemcy każdego dnia, nie tylko w ten uprzywilejowany, na kłamstwo zwodzą ${ }^{34}$.

Ten sąd pojawia się zresztą często, ze szczególną goryczą 5 maja 1776 r., gdy Stackelberg

lubo dawniej imieniem najjaśniejszej monarchini swojej uczynił był deklarację, że sołdaty onej po zakończonym sejmie pójść i nie oprzeć się aż w stolicy moskiewskiej mieli, teraz atoli uczynił drugą pierwszej wcale przeciwną, że nie tylko wojska znajdujące się już w Rze[czy]p[ospo]l[i]tej nie wyjdą z kraju, ale ich jeszcze więcej przybędzie ${ }^{35}$.

Widział dużą rolę Stackelberga w dementowaniu doniesień o sukcesach wojsk tureckich w starciach z armią rosyjską. W odpowiedzi „z jego gabinetu nie inne wychodzą wiadomości, tylko że Moskale Turków tam po kilka, po kilkanaście tysięcy znoszą"36.

\section{Potępienie polskiej naiwności}

Podziwiając zręczność władców i ich dyplomatów, jednocześnie dziwił się naiwności Polaków. Po raz pierwszy, tuż po I rozbiorze, zauważył zręczność Austriaków, którzy w zajętej Galicji początkowo nie wybierali nowych podatków i nie nękali szlachty nadmiernymi dostawami żywności, dzięki czemu ich panowanie nie budziło sprzeciwu, czy nawet rodziło nadzieje na wycofanie się z rozbiorów ${ }^{37}$.

Znacznie częściej tego typu opinie formułował w pamiętnikach, gdy znał już efekty wcześniejszych decyzji. Wiele pisał zwłaszcza o okolicznościach zawarcia sojuszu

32 J. Kitowicz, Korespondencja, s. 107. Jako zdecydowany przeciwnik Rosji został odwołany w 1772 r. Por. J. Michalski, Dyplomacja polska, s. 537.

33 J. Kitowicz, Korespondencja, s. 289-290.

${ }^{34}$ Ibidem, s. 194.

35 Ibidem, s. 306.

36 Ibidem, s. 171.

37 Ibidem, s. 164, 170. 
z Prusami w czasie Sejmu Wielkiego, ubolewając nad polską łatwowiernością, która pozwoliła na realizację pruskich planów.

Polacy długo rozmyślali, czy się mają związać przyjaźnią z królem pruskim, czyli też zostawać w bezstronności takiej jak z innymi sąsiadami; doświadczyć go wprzód chcieli, jeżeli ta przychylność, którą im ten monarcha zaraz od początku sejmu teraźniejszego zaczął okazywać, pochodzi z samej wspaniałości serca, wyzwolić Polaków z podległości moskiewskiej (z czym się zawsze Prusak oświadczał), czyli też bierze pobudkę jakowej korzyści z Polaków. Więc zanieśli do niego przez posła swojego w Berlinie dwa niniejsze żądania: Pierwsze, aby król jmć pruski raczył pożyczyć na prędsze wystawienie wojska sejmem uchwalonego sześciu milionów talarów, na co ministerium pruskie dało odpowiedź, iż z chęcią wielką pożyczy im król jmć pruski żądanej kwoty, ale żeby mu tymczasem Rzeczpospolita Polska oddała w zastaw ziemię wschowską, województwa poznańskie i kaliskie. Drugie, aby król jmć pruski raczył zniżyć na komorach swoich cła wodne od towarów do Gdańska spławianych, na co też pruskie ministerium z podobną pierwszej uprzejmością odpowiedziało, iż zniży cło król jmć, byle Polacy ustąpili mu miasta Torunia ze swoim territorium, starostwa dybowskiego z wszystkimi włościami do niego należącymi, miasta Gdańska i obydwóch brzegów Wisły aż po miasto Płock ${ }^{38}$.

Wobec polskiego niezadowolenia z takich odpowiedzi król pruski miał szybko oświadczyć, że nic nie wiedział ani o polskich propozycjach, ani o udzielonych na nie odpowiedziach ministerium pruskiego i zapewnił,

iż on nie tylko żadnego nowego nabytku nie żąda od Polaków, ale też, i owszem, chęć ma jedyną utrzymywać Rzeczpospolitą Polską przy wszelkich onej dzierżawach i krajach [...] Tak chytra i szyperska polityka pruskiego dworu, niczym od przodków swoich nieodrodna, powinna była Polaków na zawsze od pomienionego monarchy oddalić, ale chytry prostego i łatwowiernego potrafi z jednych sideł napędzić w drugie ${ }^{39}$.

W swoich uwagach „nad aliansem” ${ }^{” 0}$ z 1790 r. podkreślił, że

Król pruski zaraz od wstąpienia swego na tron zamierzał wydrzeć Polaków z opieki moskiewskiej, a podprowadzić ich pod swoją, ale że widział, jak Polacy boleśnie znosili nad sobą moskiewską gwarancją [...] nie chciał przychodzić do Polaków w postaci gwaranta, wolał przybrać postać przyjaciela i sprzymierzeńca. Dorozumiewać się jednak można z procederu jego ministra, iż ma zamiar tak wodzić Polaków za swoimi interesami, jak wodziła Moskwa ${ }^{41}$.

${ }^{38}$ J. Kitowicz, Pamiętniki, s. 427-428. Było to nawiązanie do planów ministra Ewalda Hertzberga, przedstawianych w bardzo ogólnej i nieprecyzyjnej formie. Por. J. Michalski, Dyplomacja polska, s. 612.

39 J. Kitowicz, Pamiętniki, s. 428.

40 W oparciu o ostateczne wyniki sojuszu z Prusami mógł potępiać przywódców Rzeczypospolitej, że dopiero „po zawartym traktacie z królem pruskim, gdy postrzegli, że ta ściana, której oni tak mocna dufali, jest słaba i zdradliwa; kiedy naleganie króla pruskiego o oddanie sobie Torunia i Gdańska i inne coraz nowe tegoż monarchy otworzyły oczy Polakom, że nie masz komu wierzyć”. Por. ibidem, s. 462.

${ }^{41}$ Ibidem, s. 433. Szerzej o obłudnej polityce pruskiej, zmierzającej początkowo tylko do odrzucenia planów przymierza polsko-rosyjskiego pisze Z. Zielińska, Dwa niezrealizowane projekty polityczne 
Tu szczególnie krytykował Giralomo Lucchesiniego, który

zrażony na pierwszym wstępie szacherstwa swego, nie popierał ułożonego projektu, bo też i oszukaństwo ma swoje stopnie, nie naciera wciąż, ale przemiany ustępując i następując, aby tak oswoiwszy się z nieostrożnym zadufanym, chytrzej go i snadniej swego czasu osiodłało. Umilkł tedy na chwilę Luchezyni z swoim projektem względem utworzenia nowej Rady, wyperswadował Polakom, że jego monarcha nie chce Gdańska i Torunia, że odezwa o te miasta $\mathrm{i}$ inne kraje polskie uczyniona była tylko od ministrów jego ${ }^{42}$.

Bardziej chyba jednak ubolewał nad postawą sejmujących:

Tu się jeszcze tylko ta uwaga kładzie nad zaślepieniem czy przekupieniem Stanów sejmujących, że lubo mieli tylko przykładów dawniejszych zdrady pruskiej, że lubo się podobnej i od teraźniejszego Wilhelma [Fryderyka Wilhelma II] spodziewać powinni byli, przecież, jakby nigdy nic fałszywego w Prusaku nie znaleźli, tak się gorąco do zawarcia z nim aliansu pospieszyli. Nabijano, prawda, głowę Polakom, jako się wyżej rzekło, że się Polska bez związku z jaką drugą potencją dwom mocarstwom cesarskim poźrzeć ją i szarpać czuwającym nie oprze ${ }^{43}$.

Pomimo tak negatywnej, ogólnej oceny polityki Prus, nieco inaczej podchodził do pruskich planów rozpoczęcia wojny z Austrią ${ }^{44}$. W tej sprawie, mimo nieufności do Prus, Kitowicz żałował niewykorzystanej okazji zaatakowania Austrii i odzyskania przynajmniej części Galicji, wskazując na postawę cesarskich urzędników gotowych do ucieczki, jak też na charakter Leopolda II, którego uznawał za „bojaźliwego”5.

\section{Ocena położenia Polski}

Oprócz wskazywania na polską łatwowierność, słusznie dopatrywał się istotnej przyczyny niepowodzeń działań Rzeczypospolitej na arenie międzynarodowej w jej słabości militarnej. Po raz pierwszy zauważył tę słabość w trakcie polsko-rosyjskich rokowań

Katarzyny II z początku 1789 r., [w:] eadem, Studia z dziejów stosunków polsko-rosyjskich w XVIII wieku, Warszawa 2001, s. 160.

${ }^{42}$ J. Kitowicz, Pamiętniki, s. 434-435.

43 Ibidem, s. 435. Niezbyt wierzył w samo zaślepienie i raczej doszukiwał się przekupstwa, opierając swoje domniemania na ilości pruskich talarów, które pojawiły się w Warszawie i w całym kraju, co nie wiązało się ze zwiększeniem eksportu do Prus. Por. ibidem, s. 436.

${ }_{44}$ „[K] ról pruski puszczał odgłos, że następca po Józefie, Leopold, chce mu wydrzeć Szląsk, którego on nie tylko bronić, ale też i resztę tego kraju przy domu austriackim pozostałego opanować zamyśla. $\mathrm{Na}$ ten koniec począł ruszać wojska swoje ku Górnemu Szląsku, animując Polaków, żeby też i oni z swojej strony zabierali się do odzyskania Wieliczki i innych krajów Galicji i Lodomerii, sobie wydartych [...] Jedni utrzymują, iż król pruski chciał Polaków wciągnąć w wojnę z cesarzem, aby tym łatwiej mógł ich przymusić do ustąpienia sobie Gdańska i Torunia, którego dusznie pragnie”. Ibidem, s. 472-473.

${ }^{45}$ Ibidem, s. 475. 
w 1761 r. w Toruniu dotyczących wypłaty należności z tytułu dostaw dla wojsk rosyjskich. Wówczas polscy komisarze musieli praktycznie bez sprzeciwu przyjmować redukcję wysokości pretensji polskich dostawców wobec groźby całkowitego odrzucenia roszczeń przez Stefana Puczkowa, co stało się podstawą do licznych nadużyćc ${ }^{46}$.

Sarkastycznie też podsumował 20 grudnia 1772 r. żądania zaborców w sprawie zwołania sejmu pod groźbą, ,że jeżeli Rzeczpospolita nie uczyni zadosyć tej prośbie, aprobując to wszystko za sprawiedliwy wziątek, co utraciła, to potencje sprzymierzone uczynią z nią to, co się im będzie podobało. Czyż może być coś nadto słuszniejszego?’’47. Widział jednak, że nawet Anglia nie może zrealizować swoich celów politycznych, gdy wysłała do Warszawy swojego posła Thomasa Wroughtona. Miał on jakoby zażądać dopuszczenia do rokowań z Rzeczpospolitą na takich samych zasadach, jak reprezentanci państw zaborczych. „Na co stany polskie i z niemi trzej ministrowie zwłóczą odpowiedź, aż by się tym czasem skończyła delegacja, po której już nie zostanie dla posła angielskiego materii do traktowania" ${ }^{\text {"48 }}$.

Jednocześnie wskazywał na bardzo mocną pozycję Prus, które mogły pozwolić sobie nie tylko na lekceważenie Polski, ale nawet na wysuwanie wobec Stackelberga żądań wycofania rosyjskich oddziałów z terenów, o które postanowiły powiększyć swój zabór ${ }^{49}$. Następnie (30 IV 1777) podjął spekulacje nad możliwością sojuszu prusko-francusko-tureckiego przeciw Rosji i Austrii, jak też o wkraczaniu wojsk pruskich na Żmudź i do Kurlandii, która miała stać się nagrodą za ograniczenie innych korzyści w Polsce ${ }^{50}$.

Ubolewał nad tonem listu pruskiego generała Roberta Lentulusa do biskupa Antoniego Ostrowskiego, w którym stwierdził, że Prusy nie wycofają się z zajętych ziem nawet o stopę, przypominając zasadę Beatus qui tenet („błogosławiony, kto posiada”) ${ }^{51}$. Podkreślał też obłudę Prus w traktowaniu Gdańska, którego zgodnie z traktatem rozbiorowym nie zajęły, ale wytyczyły granicę na jego przedmieściach, które uznały za odrębny organizm ${ }^{52}$.

${ }^{46}$ Ibidem, s. 92-94. Rokowania ze strony polskiej miał według Kitowicza prowadzić starosta czerwonogrodzki Wychowski, chociaż prawdopodobnie był to Stanisław Kostka Gadomski. Por. T. Ciesielski, Generatowie wojsk koronnego w latach 1717-1763, [w:] Organizacja armii w nowożytnej Europie: struktura - urzędy-prawo - finanse, Zabrze 2011, s. 465.

47 J. Kitowicz, Korespondencja, s. 116.

48 Ibidem, s. 228. Tutaj przesadnie oceniał cele rezydującego w Warszawie Wroughtona, gdyż dla Anglii najważniejsze było utrzymanie przyjaznych stosunków w Rosją. Por. Z. Libiszowska, Misja polska w Londynie w latach 1769-1795, Łódź 1966, s. 17.

${ }^{49}$ J. Kitowicz, Korespondencja, s. 219 . O osłabieniu pozycji Rosji miały też świadczyć nieoficjalne wiadomości od Franciszka Ksawerego Branickiego, będącego z misją w Petersburgu, gdzie pomimo sympatii dla Polski wskazano na niemożność udzielenia jej skutecznej pomocy (19 V 1774). Por. ibidem, s. 235. Branicki zresztą nie dostąpił zaszczytu oficjalnej audiencji i musiał zadowolić się prywatną rozmową z Nikitą Paninem (ibidem, s. 246).

${ }^{50}$ Ibidem, s. 227.

${ }^{51}$ Ibidem, s. 244.

52 Ibidem, s. 249; D. Dukwicz, Rosja wobec sejmu, s. 263-266. 
Ten pesymizm ocen położenia kraju pogłębiał się z latami. Kitowicz dostrzegał zagrożenie właściwie ze wszystkich stron: Grigorija Potiomkina marzącego o polskim tronie i psującego obrady sejmowe za pośrednictwem Franciszka Ksawerego Branickiego, Prus starających się o oderwanie części Polski, Moskwy dążącej do przywrócenia swojego panowania i wreszcie Stanisława Augusta, który „wzdychając z cicha do sukcesji tronu dla swojej familii, choć nie psuje intrygami dobrych zamysłów wielu poczciwych obywatelów, to też ani przeszkadza tym, którzy psują; siedzi spokojnie, jakby nie rozumiał, co się dzieje" ${ }^{53}$. W rezultacie pozbawiona sił Polska, skrępowana kontrolą rosyjską po klęsce 1792 r., mogła tylko udawać w nocie swojego kanclerza Jacka Małachowskiego, że nie wierzy, by wkraczanie wojsk pruskich było zgodne z wolą króla Fryderyka Wilhelma II ${ }^{54}$.

$\mathrm{Z}$ całkowitym brakiem wiary przyjmował wszystkie próby ratowania kraju przez króla Stanisława Augusta. Uwidoczniło się to już w 1773 r., gdy bez słowa komentarza udostępnił informację o przekazaniu przez Stanisława Augusta noty do trzech mocarstw z propozycją powołania mediatora. Nota ta zresztą spotkała się z ostrą reakcją wojewody gnieźnieńskiego Augusta Sułkowskiego (ściśle związanego z rosyjską ambasadą), krytykującego króla za jej wystosowanie bez wcześniejszego uzgodnienia z senatem ${ }^{55}$. Nie uwierzył też później w powodzenie desperackiego planu Stanisława Augusta, który chciał uratować Polskę poprzez powołanie na tron carewicza Konstantego Pawłowicza i jego małżeństwo z elektorówną saską i wraz z nią przejęcie tronu carskiego. Dzięki temu „Polska mogła się stać panią Rosji oraz straszną potencją całej Europy. Takimi imaginacjami, czyli z szczerej chęci pochodzącymi, czyli z obłudnej, przywiódł raz Polaków, iż z łatwością taką przystąpili do konfederacji targowickiej" ${ }^{56}$.

\section{Zakończenie}

Kończąc prezentację poglądów ks. Jędrzeja Kitowicza, należy uznać, że pomimo pełnienia funkcji kościelnych nie stał się moralistą. Nigdy nie oceniał polityki i dyplomacji z pespektywy kaznodziei. Wręcz przeciwnie, w jego korespondencji i zapiskach pełno jest słów uznania dla skutecznej polityki, a nawet dla obłudnego sposobu jej prowadzenia. Jeśli potępiał coś w życiu politycznym, to łatwowierność i bezkrytyczne przyjmowanie zapewnień o przyjaźni i gotowości do udzielenia pomocy. W tym zakresie uwagi te odnosiły się do społeczeństwa polskiego i Stanisława Augusta, chociaż w jego przypadku doszukiwał się raczej obrony własnej pozycji i interesów rodziny.

53 J. Kitowicz, Pamiętniki, s. 467.

54 Ibidem, s. 552.

55 Zaznaczył tylko, że Sułkowski kieruje się nienawiścią do dworu (J. Kitowicz, Korespondencja, s. 119).

${ }^{56}$ J. Kitowicz, Pamiętniki, s. 623. Koncepcje powołania na tron Konstantego Pawłowicza wysuwane były w 1792 r. również przez stronnictwo patriotyczne (w tym Adama Czartoryskiego, Ignacego Potockiego i Hugona Kołłątaja). Por. J. Michalski, Dyplomacja polska, s. 647-649, 654. 
Cechą charakterystyczną jego wizji politycznej była głęboka nieufność do Prus jako zainteresowanych osłabieniem i rozbiorami Rzeczypospolitej. Jednocześnie wysoko oceniał skuteczność ich polityki i dyplomacji, skutecznie wpływającej na postawy i decyzje Polaków, zwłaszcza w okresie Sejmu Wielkiego. Wiązało się to z jego słusznym przekonaniem, że ostatecznie o skuteczności wszystkich działań politycznych decyduje siła militarna państwa i możliwość jej wykorzystania w bieżącej polityce. Stąd rodziła się myśl o konieczności porozumienia się Rzeczypospolitej z Rosją jako najsilniejszym sąsiadem oraz o szkodliwości wiary w możliwość jej osłabienia w czasie kolejnych wojen, co jednak może dziwić w przypadku dawnego konfederata barskiego ${ }^{57}$.

W swoich ocenach wyraźnie kierował się doświadczeniem z okresu pisania „gazetek”, gdy docierały do niego sprzeczne nieraz informacje polityczne, których ilość nie ułatwiała zrozumienia sytuacji. Wówczas nie mógł uwierzyć w warunki pokoju w Küczük Kajnardży, zwłaszcza w rezygnację Turcji ze zwierzchnictwa nad Krymem. „Zrazuśmy się śmiali z pokoju między Turkiem i Moskwą, po tym byliśmy zamieszani matactwem tak, iż nie mogliśmy rozeznać, gdzie jest prawda..."58. Już wtedy pojawiło się zwątpienie w wartość dyplomacji, w skuteczność rokowań dla sprawy polskiej. Zwłaszcza po wstąpieniu nam tron Ludwika XVI i jego sojuszu z Austrią nie wierzył już w możliwość odwołania się do pomocy innych państw. Uznał, że z tych rozmów i układów nic nie wynika, a położenie Polski staje się coraz gorsze wobec tracenia kolejnych ziem i zagrożenia dalszymi uzurpacjami59 ${ }^{59}$ To przekonanie żywił również w czasach Sejmu Wielkiego i później.

\begin{abstract}
The article of opinion Jędrzej Kitowicz it does not it treat as source to meeting treat the secrets of policy only as example the opinions of average of nobility and lower clergy. It with this regard it is not essential treat the settlement the of events real run the exhibition on the current opinions of Polish society of kelter of diplomacy and attitudes and methods of working of diplomatists. In result article represents credulity Jędrzej Kitowicz, which he condemned simultaneously sharply Polish politicians' credulity. He in his descriptions of events united reluctance in the face of diplomatists and rulers with surprisingly high acknowledgement for negative features of diplomacy, especially hypocrisy and cleverness. He refused Polish policies diplomatic talents, he in what looked for the sources of fall of country though he had seen in lack of real strength of state of principle his cause.
\end{abstract}

Keywords

Jędrzej Kitowicz, Polish-Lithuanian Commonwealth, diplomacy, diplomatists.

57 W tym poglądzie zgodny był z tak często przez siebie krytykowanym królem, który w listopadzie 1788 r. przestrzegał sejmujących przed zerwaniem z Rosją. Por. W. Kalinka, Sejm Czteroletni, t. I, Warszawa 1991, s. 182-190.

58 J. Kitowicz, Korespondencja, s. 269.

59 W liście z 4 VII 1774 r. (ibidem, s. 256). 